\title{
Use of Cell Phone in Receiving Agricultural Information by the Farmers
}

\author{
Sk. Md. Nur-E-Alam (Corresponding author) \\ Lecturer, Department of Agricultural Extension and Information System \\ Sher-e-Bangla Agricultural University \\ Prof. Dr. Md. Sekender Ali \\ Pro-Vice Chancellor, Sher-e-Bangla Agricultural University \& Professor, Department of \\ Agricultural Extension and Information System \\ Sher-e-Bangla Agricultural University
}

Prof. M. Zahidul Haque

Professor, Department of Agricultural Extension and Information System

Sher-e-Bangla Agricultural University

Received: October 13, 2019 Accepted: November 12, 2019 Published: November 18, 2019

doi:10.5296/jfi.v3i1.15846 URL: http://dx.doi.org/10.5296/jfi.v3i1.15846

\begin{abstract}
Cell phone is an easy, fast and convenient device for communication. The main purpose of the study was to determine the extent of use of Cell Phone in receiving agricultural information and to explore the relationship between the selected characteristics of the farmers in using Cell Phone for receiving agricultural information. Data were obtained from 97 Cell Phone user farmers in selected village named Chorjamalpur of Boyra union under Singair upazila of Manikganj through face-to-face interview. Appropriate scales were developed in order to measure the concerned variables. Pearson Product Moment Correlation test was used to ascertain the relationship between each of the selected characteristics of the farmers with their use of Cell Phone for receiving agricultural information. The finding shows that 89.7 percent of the respondents had no use to low use of Cell Phone for receiving agricultural information and 10.3 percent of the respondents had medium use to high use of Cell Phone for receiving agricultural information. The finding clearly indicates the ignorance of the
\end{abstract}


respondents about the use of Cell Phone for receiving agricultural information. Among 11 selected characteristics of the farmers, eight characteristics namely, education, land possession, effective farm size, annual family income, agricultural training exposure, organizational participation, innovativeness, cosmopoliteness showed significant and positive relationship with their use of Cell Phone. Problem confrontation of the farmers in using Cell Phone showed significant negative relationship with their use of Cell Phone for receiving agricultural information. But age of the farmers and farming experience of the farmers showed non significant relationship with the use of Cell Phone by the farmers.

Keywords: use of cell phone, pearson product moment correlation

\section{Introduction}

Bangladesh being an agricultural country, the importance of the agriculture sector has long been recognized by the Government of Bangladesh (GoB). To make the agricultural sector as an engine for economic development the adoption of technology is a must. The dissemination of information communication technologies (ICTs) in developing countries provides much opportunity to transfer knowledge and information through private companies and government departments. During the last few years coverage by cell phone has spread fast in Bangladesh. According to Bangladesh Telecommunication Regulatory Commission (BTRC), the total number of Cell Phone subscriptions has reached 133.720 million at the end of December, 2015. Cell phones have provided new approach to farmers to make tentative decisions much more easily than before.

Information-based, decision-making agricultural system (Precision Agriculture) is designed to maximize agricultural production and is often described as the next great evolution in agriculture. The combination of Global Positioning System (GPS) and mobile mapping are supposed to provide farmers with the information for implementation of decision-based Precision Agriculture (Michael, 2008). FISCHER et al. (2009) emphasize that ICT has great potential and should be given the same importance as biotechnology revolution. In the context of India, the impact of mobiles as a mode of providing information for farming will depend on the how mobile networks are able to link the farmers to the market information in a timely and accurate manner

Broadly speaking, technology is the "relationship between inputs and outputs" (Foster and Rosenzweig, 2010), or the set of hardware (physical) and software (techniques) tools that allow for a different mapping of inputs to outputs. In the context of agriculture, hardware refers to improved cultivars (seeds), fertilizers and pesticides, whereas software refers to practices such as inter-cropping, mulching, and integrated pest management. We can define adoption of technology as the "use of new tools or techniques that relate inputs to outputs and the allocation of inputs" (Foster and Rosenzweig, 2010).

Different Government Organizations (GOs) and Non- Government Organizations (NGOs) are trying with diverse initiatives for strengthening the agriculture sector of Bangladesh. Though various efforts of improvement are in there, but the agriculture sector is facing a range of challenges for its development like over population, political instability, climate change, loss 
of agricultural land, infertile land, use of excessive pesticides, lack of inputs, improper irrigation etc. For providing agricultural information to the farmers GOs and NGOs has taken some time befitting initiatives. The Government of Bangladesh has established Agricultural Information Service (AIS) through which training guides, newsletters, radio \& TV programs, films etc. are arranged for disseminating information. In 2010, AIS has developed SMS based information service with the help of a mobile operator Banglalink ${ }^{\text {ee }}$ and UNDP in the country. Since October 2008, an e-agriculture initiative known as "e-Krishok" has been using information and communication technologies to deliver information and advisory services to farmers in rural and remote locations at a lower cost.

In 2009, Ministry of Agriculture in Bangladesh with support from UNDP Bangladesh has initiated Agriculture Information and Communication Centers (AICC) in 20 areas. And agricultural information service has piloted 10 farmers community based Call Centers in those twenty areas (ebangladeshexpo, 2013).

Despite those initiatives, most of the farmers of Bangladesh are still in lack of information and modern agricultural knowledge. They need an easy access point to get and meet their information need. Information need has three basic elements: availability, access and utilization. But the GOs and NGOs initiatives are hard to reach and they lack ease of use by the farmers. Under the above circumstances, this study has tried to measure the contribution of cell phones in disseminating agricultural information in Bangladesh.

There is room for significant growth in operator involvement in reaching the 22 million agricultural workers that have mobile phones; in addition, by offering mobile agriculture services operators have the potential to attract 14 million new customers to their subscriber base by giving them a reason to connect that they may not have had previously. Robi, Banglalink and Grameenphone are currently offering mobile agricultural services, mainly providing market information, agricultural news and weather information via interactive voice response (IVR) or native voice services in both Bangla and English. However, these services have not scaled yet; a study carried out by Katalyst and The Springfield Centre estimates that 200,000 farmers benefitted in 2012 from the two mAgri services offered by Banglalink and Grameenphone4. This is a significant number, but i illiteracy among the target audience. However, we believe there is still a lack of awareness of these services and their value proposition (especially important for individuals with low disposable incomes). Operators and co-operatives can play a larger role in improving this, such as through rural distribution centre's and below the line advertising.

\subsection{Specific Objectives of the Study}

The following specific objectives were formulated in order to give proper shape to the research work:

1. To determine the following selected characteristics of the farmer:

2. To assess the extent of use of cell phone by the farmers for receiving agricultural information 


\section{Macrothink}

3. To explore the relationship between each of the selected characteristics of the farmers and their use of Cell phone for receiving agricultural information

\section{Methodology}

\subsection{Locale of the Study}

The study was conducted in Singair upazilla of Manikganj district of Bangladesh. The researcher selected cell phone user farmers of the Boyra union in this upazilla. Charjamalpur Village of Boyra union constituted the locale of the study.

\subsection{Population and Sampling Design}

All the cell phone user farmers of the Chorjamalpur village of Boyra union of Singair upazilla of Manikganj District constituted the population of the study. For this purpose, an up-to-date list of the cell phone user farmers was prepared with the help of the village elites and Sub-assistant Agricultural Officers of that union. The total number of the cell phone user's farmers in this village was 106. Attempt had been made to collect data from all the 106 cell phone user farmers of the village. But unfortunately, 9 farmers were not available at the time of data collection. Hence, the sample of the study become 97.

\subsection{Instrument for Collection of Data}

In order to collect relevant information an interview schedule was carefully prepared and designed in keeping the objective of the study in view. The statements and questions were set with wide revision and they were made simple and easily understandable to the farmers. It contained both open and closed form questions. It contained eleven independent variables. The questions were arranged systematically. The interview schedule was pretested with 10 cell phone user farmers and then final shape was given to the interview schedule according to the experience of pre-test. The pre-test facilitated the researcher to examine the suitability of different questions and status of the instrument in general.

\subsection{Use of Cell Phone for Agricultural Information}

Extent of use of cell phone was measured by the number of successful use of five selected cell phone services in last three months

\subsection{Hypotheses}

\subsubsection{Research Hypotheses}

The following research hypotheses were put forward to test the relationship of the selected characteristics of the farmers and their use of cell phone by the farmers for receiving agricultural information.

"There is relationship between each of the selected characteristics of the farmers and their use of cell phone for receiving agricultural information. The selected characteristics include: age, education, land possession, effective farm size, farming experience, annual family income, agricultural training, organizational participation, innovativeness, cosmopoliteness and problems confronted by the farmers in using cell phone for receiving agricultural 


\section{Macrothink}

information".

\subsubsection{Null Hypotheses}

For statistical test of the research hypotheses they were converted to null form. The null hypotheses were as follows:

$\mathrm{H}_{0}$ : "There is no relationship between each of the selected characteristics of the farmers and their use of cell phone for receiving agricultural information."

\subsection{Collection of Data}

Data were collected by the researcher himself during 10 January to 12 February, 2016. To get valid and pertinent information, the researcher made all possible efforts to explain the purpose of the study to the respondents.

Interviews were executed with the respondents in their residents during their leisure period. While interviewing with any respondents, the researcher took all possible care to establish rapport with him/her so that he/she did not get feel awkward and unexpected situations to furnish proper responses to the questions and statements in the schedule. The questions were clearly explained wherever the respondents felt any unwanted situation or feelings.

\subsection{Data Processing}

\subsubsection{Editing}

The collected raw data were examined thoroughly to detect errors and omissions. As a matter of fact the researcher made a careful scrutiny of the completed interview schedule to make sure that necessary data were entered as complete as possible and well arranged to facilitate coding and tabulation. Very minor mistakes were detected by doing this, which were corrected promptly.

\subsubsection{Coding and Tabulation}

Having consulted with the research supervisor and co-supervisor, the investigator prepared a detailed coding plan. In case of qualitative data, suitable scoring techniques were followed by putting proper weight age against each of the traits to transform the data into quantitative forms. These were then tabulated in accordance with the objective of the study.

\subsubsection{Categorization of Data}

Following coding operation, the collected raw data as well as the respondents were classified into various categories to facilitate the description of the independent and dependent variables. These categories were developed for each of the variables by considering the nature of distribution of the data and extensive literature review. The procedures for categorization have been discussed while describing the variables under consideration in chapter 4.

\subsection{Statistical Analysis}

The statistical measures such as range, percentage, mean, standard deviation were used for describing the variables. Tables were also used in presenting data for clarity of understanding. 


\section{Macrothink}

Pearson Product Moment correlation was run to determine the relationship between each of the selected characteristics of the farmers with their use of cell phone for receiving agricultural information. Five percent (0.05) level of probability was used as the basis for rejection of any null hypothesis throughout the study.

\section{Results and Discussion}

\subsection{Selected Characteristics of the Farmers}

In this section the findings of the farmers' selected characteristics have been discussed. The selected characteristics are i) Age, ii) Education, iii) Land possession, iv) Effective farm size, v) Farming experience, vi) Annual family income, vii) Agricultural training exposure, viii) Organizational participation, ix) Innovativeness, $\mathrm{x}$ ) Cosmopoliteness and xi) Problems confronted by the farmers in using cell phone for receiving agricultural information.

The salient features of the selected characteristics of the farmers like possible and observed range, number and percent distribution, mean, standard deviation and categorization are presented in Table 1.

\subsection{Use of Cell Phone in Receiving Agricultural Information by the Farmers}

The computed cell phone using scores ranged from 0-8 with an average of 1.19 and a standard deviation of 1.71.Based on their cell phone using scores the respondents were classified into four categories as "no user", "low user", "medium user" and "high user". The distribution of the farmers according to use of cell phone is shown in Table 2.

Table 1. Distribution of the respondents according to their characteristics $(\mathrm{N}=97)$

\begin{tabular}{|c|c|c|c|c|c|c|c|}
\hline Variables & $\underline{\text { Range }}$ & & Categories & $\underline{\text { Respond }}$ & & Mean & SD \\
\hline (measuring unit) & Possibl & eObserve & & Number & Perce & & \\
\hline Age & - & $16-75$ & Young $(\leq 35)$ & 26 & 26.8 & 42.53 & 11.55 \\
\hline (Years) & & & Middle Aged (36-50) & 55 & 56.7 & & \\
\hline & & & Old $(>50)$ & 16 & 16.5 & & \\
\hline Education & - & $0-16$ & Illiterate $(0)$ & 8 & 8.2 & 5.83 & 3.71 \\
\hline (Year of schooling) & & & Primary (1-5) & 37 & 38.2 & & \\
\hline & & & Secondary (6-10) & 50 & 51.5 & & \\
\hline & & & Higher Secondary (10-12) & & 2.1 & & \\
\hline Land Possession & - & $0.03-2.1$ & 0 Marginal (up to $0.20 \mathrm{ha}$ ) & 10 & 10.3 & 0.58 & 0.39 \\
\hline (Hectare) & & & Small (0.21-1.0 ha) & 77 & 79.4 & & \\
\hline & & & Medium (1.01-2.5 ha) & 10 & 10.3 & & \\
\hline
\end{tabular}


Effective Farm Size 0.04-2.02 Marginal (up to 0.20 ha) 8

8.2

$\begin{array}{ll}0.173 & 0.33\end{array}$

(Hectare)

Small (0.21-1.00 ha) $\quad 80$

82.5

Medium (1.01-2.5 ha) 9

9.3

Farming Experience

Low $(<21)$

33

$34 \quad 27.05 \quad 11.47$

(Years)

Medium (21-35)

47

48.5

High (>35)

17

17.5

Annual Family Income

60-390 Low $(<101.3)$

41

$42.3 \quad 138.3574 .10$

Medium (101.3-175.4) 33

34

('000’ Tk)

High (>175.4)

23

23.7

\begin{tabular}{|c|c|c|c|c|c|c|c|}
\hline \multicolumn{2}{|l|}{ Agricultural Training exposure- } & $0-21$ & No $(0)$ & 57 & 58.8 & 1.07 & 3.00 \\
\hline \multirow[t]{2}{*}{ (Days) } & & & Low(1-2) & 36 & 38.1 & & \\
\hline & & & Medium (Above 2) & 4 & 3.1 & & \\
\hline \multirow[t]{3}{*}{ Organizational Participation } & - & $0-7$ & $\mathrm{No}(0)$ & 32 & 33 & 1.86 & 1.80 \\
\hline & & & $\operatorname{Low}(1-3)$ & 47 & 48.4 & & \\
\hline & & & Medium (4-7) & 18 & 18.6 & & \\
\hline \multirow{3}{*}{$\begin{array}{l}\text { Innovativeness } \\
\text { (Score) }\end{array}$} & $0-60$ & $11-38$ & Low $(<22)$ & 29 & 29.9 & 24.17 & 4.91 \\
\hline & & & Medium (22-26) & 38 & 39.2 & & \\
\hline & & & $\operatorname{High}(>26)$ & 30 & 30.9 & & \\
\hline \multirow{4}{*}{$\begin{array}{l}\text { Cosmopoliteness } \\
\text { (Score) }\end{array}$} & $0-21$ & $0-21$ & $\operatorname{No}(0)$ & 2 & 2.1 & 14.03 & 4.07 \\
\hline & & & Low $(1-7)$ & 2 & 2 & & \\
\hline & & & Medium (8-14) & 47 & 48.5 & & \\
\hline & & & $\operatorname{High}(15-21)$ & 46 & 47.4 & & \\
\hline \multirow{3}{*}{$\begin{array}{l}\text { Problems in using cell } \\
\text { phone for } \\
\text { Receiving agricultural } \\
\text { information(score) }\end{array}$} & $0-24$ & $05-13$ & Low $(<9)$ & 33 & 34 & 9.39 & 2.00 \\
\hline & & & Medium(9-10) & 31 & 32 & & \\
\hline & & & High $(>10)$ & 33 & 34 & & \\
\hline
\end{tabular}

Table 2. Distribution of the farmers according to use of cell phone 


\begin{tabular}{lllll}
\hline Category & No. of respondent & Percent & Mean & Standard Deviation \\
\hline No use & 45 & 46.4 & & \\
Low use & 42 & 43.3 & & \\
Medium use u & 8 & 8.2 & 1.19 & 1.71 \\
High & 2 & 2.1 & & \\
Total & 97 & 100 & & \\
\hline
\end{tabular}

3.3 Relationship between the Selected Characteristics of the Cell Phone User Farmers and their Use of Cell phone for Receiving Agricultural Information

The purpose of this section is to examine the relationships of each the eleven selected characteristics (as cited in the objectives) of the farmers with their use of cell phone in receiving agricultural information

The null hypothesis formulated as "There is no significant relationship between each of the selected characteristics of the farmers and their use of cell phone in receiving agricultural information". The hypothesis regarding the concerned variables were examined through computing Pearson's Product Moment Correlation Coefficient ( $r$ ) and findings have been shown in Table 3. 
Table 3. Relationship between the selected characteristics of the cell phone user farmers and their use of cell phone for receiving agricultural information $\mathrm{N}=97$

\begin{tabular}{lll}
\hline & Selected characteristics of the farmers & $\begin{array}{l}\text { Values of correlation } \\
\text { coefficient("r") }\end{array}$ \\
\hline & Age & $-0.039^{\mathrm{NS}}$ \\
& Education & $0.236^{*}$ \\
& Land Possession & $0.523^{* *}$ \\
& Effective farm Size & $0.509^{* *}$ \\
Farming experience & $-0.094^{\mathrm{NS}}$ \\
farmers & Annual family income & $0.558^{* *}$ \\
& Agricultural training exposure & $0.215^{*}$ \\
& Organizational participation & $0.268^{* *}$ \\
& Innovativeness & $0.493^{* *}$ \\
& Cosmopoliteness & $0.492^{* *}$ \\
& $\begin{array}{l}\text { Problem confrontation of the farmers in using } \\
\text { cell phone }\end{array}$ & $-0.430^{* *}$ \\
\hline
\end{tabular}

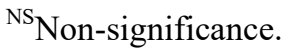

${ }^{* *}$ Correlation is significant at the 0.01 level (2-tailed).

${ }^{*}$ Correlation is significant at the 0.05 level ( 2 -tailed).
}

\section{Conclusions and Recommendations}

\subsection{Conclusion}

On the basis of the findings of the research and logical interpretations of their meaning in the light of other relevant facts, the researcher drew the following conclusions:

- The finding shows that 89.7 percent of the respondents had no to low use of Cell Phone and 10.3 percent of the respondents had medium to high use of Cell Phone for receiving agricultural information. Thus, it revealed that use of cell phone by the farmers is still confined to communicate with their family members and relatives, not for receiving agricultural information.

- Land possession and effective farm size had significant and positive relationship with their use of Cell Phone for receiving agricultural information.

- Agricultural training exposure of the farmers had significant positive relationship with 


\section{Macrothink

their use of Cell Phone for receiving agricultural information. Therefore, it may be recommended that attempts should be taken by the agricultural extension providers to arrange training for the farmers for increasing their use of Cell Phone for receiving agricultural information.

- Farming experience had no relationship with the use of Cell Phone for receiving agricultural information.

- Annual family income, Cosmopoliteness and Organizational participation of the farmers had a positive relationship with their use of cell phone. This implies that with the increase of annual family income cosmopoliteness, and organizational participation their use of cell phone is also increased.

- Innovative people are more friendly to use of cell phone. Innovativeness of the farmers had positive relationship with their use of cell phone for receiving agricultural information. So, it is concluded that with the increase of innovativeness, their use of cell phone was also increased.

- The relationship between the problem confrontation in receving agricultural information and use of Cell Phone was significant and shoed a negative trend. With the increase of problem confrontation, their use of Cell Phone was decreased and vice-versa.

\subsection{Recommendations}

Based on the findings and conclusions of the study following recommendations for policy implications were put forward:

- The finding shows that 89.7 percent of the respondents had no to low use of Cell Phone and 10.3 percent of the respondents had medium to high use of Cell Phone for receiving agricultural information. This was not a satisfactory feature. As a result, policy should be taken for increasing extent of use of cell phone for agricultural purposes through creating awareness and interest among the farmers.

- From the study, it was found that majority of the farmers feel lack of knowledge operating cell phone. Therefore, operators should take practical initiative to minimize thus type of problems.

- From the study it was clear that, cosmopoliteness has a positive trend with the use of cell phone. So, it should be encouraged among the farmers.

- Need base Agricultural information must be established to serve effective information among the farmers. Proper supervision from GO and NGO must be executed.

\section{References}

Aker, J. C. (2010): Dial 'A' for Agriculture: Using Information and Communication Technologies for Agricultural Extension in Developing Countries. Center for Global Development, Washington, DC. 


\section{Macrothink}

Fischer, R. A., Byerlee, D., And Edmeades, G. O. (2009). Can Technology Deliver On The Yield Challenge To 2050? Expert Meeting on "How to feed the World in 2050". Food and Agriculture Organization of the United Nations and Economic and Social Development Department, Rome.

Foster, A. D., \& Rosenzweig, M. R. (1995). Learning by Doing and Learning from Others: Human Capital and Technical Change in Agriculture. Journal of Political Economy, 103(6). https://doi.org/10.1086/601447

GOB. (2013). Bangladesh Economic Review. Economic Division, Ministry of Finance, Government of the People's Republic of Bangladesh, Dhaka, Bangladesh.

https://doi.org/10.2139/ssrn.1942954

Michael, R. (2008). The use of GPS and mobile mapping for decision-based precision agriculture. Retrieved from http://www.gisdevelopment.net/application/agriculture/ overview/agrio0011.htm

\section{Copyright Disclaimer}

Copyright for this article is retained by the author(s), with first publication rights granted to the journal.

This is an open-access article distributed under the terms and conditions of the Creative Commons Attribution license (http://creativecommons.org/licenses/by/4.0/). 